„Analecta Cracoviensia” 51 (2019), s. 313-341

DOI: http://dx.doi.org/10.15633/acr.3646

Cătălina Mititelu

0000-0001-6489-9252

Ovidius University of Constanta, Romania

\title{
The Oikonomia and its application in the See of the Confession
}

\section{Preliminaries}

In the Orthodox Churches, one of the Holy Sacraments is the Holy Confession, in which the Confessor is using both the "Oikonomia" (clemency) and the "Acribia" (strictness of canonical law) for the salvation of the penitent.

In these Churches "Oikonomia" has been and continues to be perceived as an "extraordinary means of salvation," that "goes beyond the action by Acribia of the Church, which the latter accomplishes by the Holy Sacraments."

In the texts of the Canons and of the Legislations of the Autocephalous Orthodox Churches, the term "Oikonomia" expresses both its special sense, namely that of extraordinarily partaking of the deifying divine grace, under certain circumstances, to fill in "what is missing" and "what has not been realized through Acribia (exactitude)," but also other "various meanings, expressed using the terms: 'condescension,' 'privilege,' 'indulgence,' 'mercy,' 'lenience,' 'love for man,' 'loosing,' 'forgiveness,' 'clemency,' 'release' etc."'

1 Iconomia în Biserica Ortodoxă (Referat al Comisiei Interortodoxe pregătitoare a Sfântului şi Marelui Sinod, Chambésy, 16-28 Iulie 1971) (Oikonomia in the Orthodox Church. Report of the Inter-Orthodox Commission preparatory for the Holy and Great Synod, Chambésy, July 16-28, 1971), "Ortodoxia" (The Orthodoxy) 24 (1972) no. 2, p. 287.

2 Iconomia în Biserica, op. cit., p. 290. 
On Oikonomia and its application in the See of the Confession, we find eloquent testimonies both in the text of the canonical Legislation, and in some works with a penitential content of certain Holy Fathers of the Eastern Church, from which some chapters or fragments were also reproduced in the text of the "Penitential Canons," which, along the centuries, have enjoyed a large circulation among the faithful Christians and among their Confessors.

Both the Confessor and the penitent have to be as familiar as possible with the text of the canonical Legislation and with the canonical Doctrine regarding the Sacrament of the Holy Confession and the application of the Oikonomia in the See of the Confession, where "the healing cure" for man's sins is applied by means of the "Canon of love for man."

Our scientific approach in the drafting of this work has been largely determined precisely by this aim, namely the desire to contribute to a better knowledge of this canonical Legislation and Doctrine about the modalities of applying the Oikonomia in the See of the Confession, by the act of forgiving and loosing the penitent from the sins committed - knowingly or unknowingly - and of making him worthy "of the final and most necessary viaticum" (Canon 13, I ${ }^{\text {st }}$ Ecumenical Synod), namely of the Holy Eucharist.

\section{In the See of the Confession, Oikonomia is perceived and applied as a "Saving Condescension" and as a "Canon of love for man"}

For Saint Nicholas I the Mystic, Patriarch of Constantinople (901-907; 912925), Oikonomia "is saving condescension helping the one who has sinned, lending [him] a merciful hand and lifting the one who has fallen from his mistake, without letting him knocked down by sin or pushed towards an abyss of sorrow."

Actually, in the See of the Confession, Oikonomia has always been perceived by the Confessor as "saving condescension" to the person confessing his sins. This condescension is expressed by leniency and compassion to the weakness of the human nature, which begs for mercy and forgiveness from the Good God for the man fallen into sin. But it is precisely in this sense of "condescension" saving the repentant that the Oikonomia in the See of the Confession

3 Nicholas the Mystic, Patriarch of Constantinople, 32nd Letter to the Pope of Rome, apud I. Kotsonis, Problèmes de l'Economie éclésiastique, éd. J. Duculot, Ganbloux 1971, p. 43. 
has been perceived from the beginning; in the Oikonomia, the "philanthropy" (love for man) showed by our Savior Jesus Christ has been a sort of "norma normans" for every Confessor of the Orthodox Church.

The dogmatist theologians affirm that "the divine Oikonomia of grace does not exclude an effort of the human instruments, in support of a wise use and application of the grace given through Oikonomia by God. And this use and application is also - they mention - an Oikonomia that is part of the divine Oikonomia in its broad and complete meaning." ${ }^{4}$ But, in the See of the Confession, the confessor is also an instrument for the wise use of the grace given through Oikonomia by God, who made out of His "priests" "faithful stewards of God's grace" (1 Pet 4:10).

According to the testimony left by an erudite canonist of the $\mathrm{IX}^{\text {th }}$ century, namely the Patriarch Photios of Constantinople, the Confessor finds in the text of the canonical Legislation "... the healing cure for mistakes, the rule leading any holy life to its immortal goal,", and, in the canonical Doctrine, the way these canons have been perceived and interpreted along the centuries regarding the penitential Discipline, wherefrom his obligation to be very familiar both with the text of the canonical Legislation and with that of the canonical Doctrine.

Regarding the application of the Oikonomia, the Orthodox canonical doctrine has insisted on the fact that "Oikonomia needs to have a serious justification, which means that we should not give up on the Acribia out of superficial reasons; we cannot use it except for really valid reasons, namely the spiritual interest of a person or of a community." But, this is all the more evident in the See of the Confession, where the Confessor can apply Oikonomia only for very serious reasons and justified by the obvious and urgent need to save the penitent from the slavery of sin.

According to the definition given by Nicholas the Mystic, Patriarch of Constantinople (901-906; 912-925), "Oikonomia is redeeming condescension

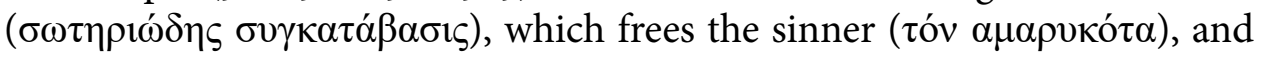

4 D. Stăniloae, Iconomia dumnezeiască, temei al iconomiei bisericeşti (The Divine Oikonomia, Basis of the Church Economy), "Ortodoxia" (The Orthodoxy) 21 (1969) no. 1, p. 8.

5 Photios, Patriarch of Constantinople, Preface to the Nomocanon in XIV Titles, in: The Athenian Syntagma, vol. 1, ed. by G. A. Rallis și M. Potlis, Athens 1852, p. 5.

6 P. L'Hullier, L'Esprit du droit canonique, in: Messager de l'Exarchat du Patriarcat Russe en Europe Occidentale, Paris 1964, p. 46-47 (apud Romanian translation in Anuarul Facultăţii de Teologie din Sibiu [The Yearbook of the Faculty of Theology of Sibiu], Sibiu, VII [2006-2007], p. 14). 
it is the helping hand hoped for...” Moreover, “... Oikonomia is the imitation

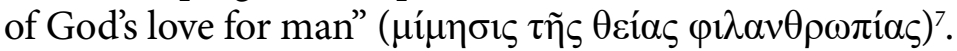

In the See of the Confession, the confessor needs therefore to have always the conscience that by Oikonomia - which is an act of "redeeming condescension" - he can effectively help the sinner, and that, by this act, he is following in the footsteps of Christ, Who, out of His divine love for mankind, made of Himself a redeeming offering for the sins of the whole mankind.

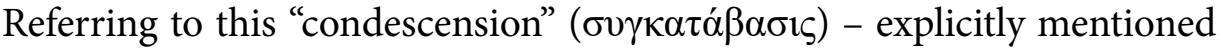
by the Patriarch Nicholas the Mystic of Constantinople - the Holy Synod of the Romanian Orthodox Church explained - in the year 1969 - that, "in brief," this means "a certain lack of severity, namely a certain moderation in the application of the Church norms ( $\tau \tilde{\omega} \nu \dot{\varepsilon} \kappa \kappa \lambda \eta \sigma \iota \alpha \sigma \tau \kappa \tilde{\omega} \nu \delta i \alpha \tau \alpha \dot{\xi} \varepsilon \omega v)$, or a certain leniency ( $\dot{\varepsilon} \pi \varepsilon \dot{\varepsilon} \kappa \varepsilon \dot{\alpha} v)$ regarding the transgression of these norms, in the sense of diminishing the penance ( $\pi$ oเvñ $\varsigma$ ), which should answer the sinner's need for recovery."

But, in the first millennium, it is precisely this lack of "severity" (Acribia), or a certain "moderation" in the application of the canonical Legislation, that characterized the modality of application of the Oikonomia, of which - by their theological works and their canonical Legislation - the Holy Fathers of the Eastern Christian Church have transmitted Rules that can guide as well even today's Confessors in the See of the Confession.

By the acts of Oikonomia used in the See of the Confession, the Confessor Bishop or the Confessor Priest actually evaluates and applies the Acribia of canonical Legislation through the prism of a human understanding, full of compassion to the sinner. But, through the prism of this comprehension - which takes into account the obvious and urgent needs of the penitent - is actually affirmed, clearly, precisely the ontological character of the humanism of the teaching of the Orthodox Church, according to which God does not want the sinner's death, but his repentance, ("that the wicked turn from his way"), and salvation (Ezek 18:23, 32; 33:11; 2 Pet 3:9).

7 Nicolai Archiepiscopi Constantinopolitani, Epistolae, accurante et denuo recognoscente J.-P. Migne, tomus unicus, Parisiis 1863, col. 212-213(Patrologiae Cursus Completus. Series Graeca $[=\mathrm{PG}], 111)$.

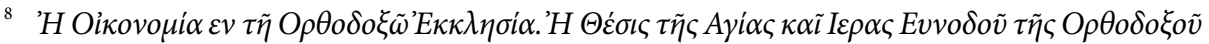

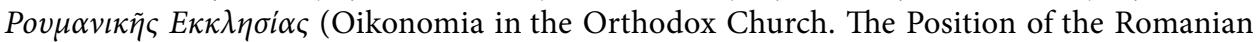
Orthodox Church Synod), translated in Greek by O. Căciulă, Bucharest 1969, p. 31. 
The Holy Scripture certifies that God "desires all people to be saved and to come to the knowledge of the truth" (1 Tim 2:4), and "whoever turns a sinner from the error of his way will save his soul from death and cover over a multitude of sins" (Jas 5:20).

By the application of Oikonomia in the See of the Confession, the Confessor actually becomes aware that the Church cannot deprive anyone of salvation (cf. Acts 14:27; 1 Tim 2:4), and, for this reason, the "Epitimias" (penances) prescribed by him to the penitent have no other goal except to help him obtain his salvation, that is "salus animarum" (the salvation of souls) (cf. can. $747 \$ 2 ; 1752$ of the Latin Code of Canon Law), which "... is the highest law of the Church."

It was said that this "supreme law" of the Church was "adopted from Roman Law,"10 that is from "Twelve Tablets of Roman Law (approx. 450 B.C.)," and about which even "Cicero" referred expressly to it."

Certainly, first of all we have to remember that this "supreme law" of the Church was given to us just by our Lord Jesus Christ (cf. Mk 16:16; Jn 6:54), and, then, to take in consideration the fact that this law regards the souls of the all people who believe in Him, and not only "the safety" or "the welfare of the (Roman) people," as Cicero asserted when he spoke about "salus populi suprema lex est."'12

In the See of the Confession, the application of the Oikonomia is clearly expressed by the loosing of the penitent from his sins, and, ipso facto, by the fact that he is made worthy to receive the Holy Eucharist. ${ }^{13}$

In the process of application of the canonical disposals and in the stating of the "Epitimias," the Confessor ought not to invoke the "formal strictness

9 T. J. Paprocki, Comment on the Canon 1752, in: New Commentary on the Code of Canon Law, ed. by J.P. Beal et all., New York 2000, p. 1847.

10 T. J. Paprocki, Comment on the Canon 1752, op. cit., p. 1847.

11 T. J. Paprocki, Comment on the Canon 1752, op. cit., p. 1847.

${ }^{12}$ For Cicero, the "suprema lex" is indeed "the salvation" or the "welfare of the people" (De Legibus, 3. 3. 38), but not the "salus animarum" (Mk 16:16; Jn 6:54).

13 About the impediments of the penitent to the Holy Eucharisty, see N. V. Dură, Rânduieli şi norme canonice privind administrarea Sfintei Euharistii (Rules and canonical Norms rearding the administration of the Holy Eucharisty), in: Spovedania şi Euharistia izvoare ale vieţii creştine (Confession and Eucharisty Sources of the Christian life), vol. 2, Bucureşti 2014, p. 465-484; C. Mititelu, The celebrant of the Holy Sacrament of the Eucharist. Rules and canonical norms of the Orthodox Church, "Annales Canonici" 2014 no. 10, p. 135-148; C. Mititelu, The application of Epitimias in the See of Confession according to the "Canonical Custom" and the "Penitential Canons", "Teologia Młodych" 2015 no. 4, p. 10-18. 
of the canon provisions," but, from case to case, he ought to try to find "the cor-

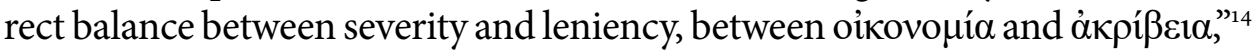
and judge the penitent's acts according to the spirit of the right judgment, namely of equity. ${ }^{15}$

The fact that, in the See of the Confession, Oikonomia ought to be preferred to Acribia, is attested both by the canonical Legislation of the Eastern Orthodox Church, and by its canonical Doctrine, according to which the notion of Oikonomia corresponds in a way to "the notion of equity from the Roman Law, which was also the notion opposed to the formal strictness of Law."16

According to the affirmation of the Holy Fathers of the Trullan Synod, "Oikonomia" is identified with " $\varphi 1 \lambda \alpha v \theta \rho \omega \pi i \alpha^{\prime \prime 17}$ (Canon 3 of the Trullan Synod), and this is why they preferred "the canon of love for man and of compassion," namely that of Oikonomia, instead of "the canon of strict conformity," namely of Acribia.

The same Father of the $\mathrm{vI}^{\text {th }}$ Ecumenical Council (Constantinople, 691/692) decided that in case which "those enlisted the Clergy," who concluded "illicit marriages," "... are weeping to the Lord to be pardoned therefor, they

${ }^{14}$ G. Cronţ, Iconomia în Dreptul bisericesc ortodox. I. Principii (Oikonomia in the Orthodox Church Law), Bucharest 1937, p. 12.

${ }^{15}$ See N. V. Dură, Ideea de Drept. "Dreptul”, "Dreptatea” şi "Morala" (The Idea of Law. The "Law", The "Justice" and The "Morals"), "Ovidius University Annals. Series: Law and Administrative Sciences” 2004 no. 1, p. 15-46; N. V. Dură, Dreptul în percepţia Părinţilor Bisericii ecumenice din primul mileniu (Law in the Perception of the Fathers of the Ecumenical Church of the First Millennium), "Revista de Teologie Sfântul Apostol Andrei" (Theological Journal Saint Andrew the Apostle) 10 (2006) no. 1, p. 7-16; N. V. Dură, Loi morale, naturelle, source du Droit naturel et de la Morale chrétienne, in: La morale au crible des religions (Studia Arabica xxI), coord. M. Th. Urvoy, Paris 2013, p. 213-233; N. V. Dură, Le jugement et la déposition des Evêques selon la legislation canonique conciliaire, œcumenique, du Ier millenaire, in: In memoriam Akademiemitglied professor Protopresbyter Dr. Stefan Tsankov, Sofia 2014, p. 117-128; N. V. Dură, Despre "Jus naturale". Contribuţii filosoficojuridice (About "Jus naturale". Philosophical-juridical contributions), "Revista de Teologie Sfântul Apostol Andrei” (Theological Journal Saint Andrew the Apostle) 18 (2014) no. 1, p. 39-52; N. V. Dură, C. Mititelu, L'École roumaine du Droit canonique et sa contribution au développent du Droit canonique de l'Église Orthodoxe Ecuménique, in: Tradiţie şi continuitate în teologia tomitană. Două decenii de învăţământ teologic universitar la Constanţa (1992-2012) (Tradition and Continuity in the Theology of Tomis. Two Decennia of Theological Higher Education in Constanta), Constanţa 2012, p. 37-6o; N. V. Dură, C. Mititelu, Human rights and their universality. From the rights of the "individual" and of the "citizen" to "human" rights, in: International Conference "Exploration, Education and Progress in the Third Millennium". Proceedings, vol. 1, no. 4, Galaţi 2012, p. 103-127.

${ }_{16}$ G. Cronţ, Iconomia în Dreptul bisericesc ortodox, vol. 1, op. cit., p. 12.

${ }_{17}$ The Athenian Syntagma, op. cit., vol. 2, p. 312. 
deserve to share in the honor of standing and sitting in the place reserved for the presidency: for to bless one that ought to take care of his own wounds is inconsistent. But, on the other hand, as for those who have contracted but one marriage, and this with a woman that was a widow, and likewise as for those who after ordination have involved themselves in an illegal marriage, that is to say, Presbyters and Deacons and Subdeacons, not long ago excluded from the sacred liturgy and penanced, we order them to be restored to their former ranks, without being in any way promoted to any higher rank, it being obvious that their illegal marriage has been dissolved... but besides this we henceforth decree and renew the Canon prescribing that anyone who has become involved in two marriages after baptism, or has acquired a concubine, cannot become a Bishop, or a Presbyter, or a Deacon, or anything else in the roll of the priesthood. Likewise in regard to anyone that has taken a widow, or a divorcee, or a harlot, or house servant, or an actress to wife, we decree that he cannot be a Bishop, or a Presbyter, or a Deacon, or anything else in the roll of the priesthood" (Canon 3 of the Trullan Synod). ${ }^{18}$

Consequently, according to the Fathers of "this Holy and Ecumenical Council" (Canon 3 of the Trullan Synod), the love for God and the love for men ought to prevail as well in the See of the Confession, namely the principle of Oikonomia should be applied, which is an eloquent testimony also in favor of the affirmation of the right to "dignitas humana," ${ }^{19}$ which the Fathers of the Church, from the first millennium, have affirmed and protected continually also by means of its canonical Legislation.

According to the affirmation of some Holy Fathers of the Orthodox Catholic Church, from the first millennium, "the principle of moderation" or of

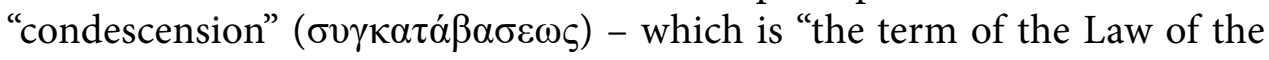
Oikonomia"2o - is valid mainly in the penitential domain, but also in the Church Discipline, in general. For example, according to the assertion of Saint

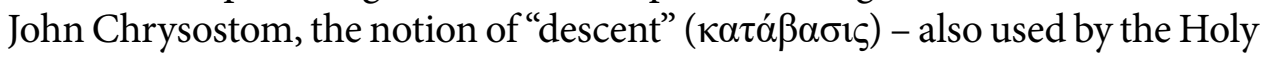

18 Apud Canoanele Bisericii Ortodoxe. Note şi Comentarii (The Canons of the Orthodox Church. Notes and Comments), ed. by I. N. Floca, Bucharest 1992, p. 103.

19 See for more details N. V. Dură, Dreptul la demnitate umană (Dignitas Humana) şi la libertate religioasă. De la "Jus naturale" la "Jus cogens" (The Right to Human Dignity (Dignitas Humana) and Religious Freedom. From "Jus naturale" to "Jus cogens"), "Ovidius University Annals. Series: Law and Administrative Sciences" 2006 no. 1, p. 86-128.

${ }^{20}$ G. Cronţ, Iconomia în Dreptul bisericesc ortodox, vol. 1, op. cit., p. 12. 
Apostle Paul to refer to his relation to his fellows of the same Religion ${ }^{21}$ - is iden-

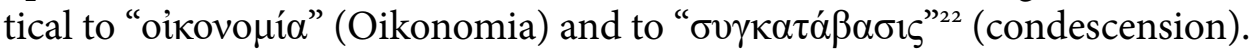

In order to preserve the penitential Discipline, the Church also established from the beginning some impediments regarding the way of application of the principle of Oikonomia in the See of the Confession. That is why not any form of "leniency" or "condescension" from the strict observation of canonical Legislation can be admitted by the Confessor, and - even less - ignoring or eluding the Canon Law.

Therefore, we need to retain the fact that "Condescension" can neither attenuate or alleviate the provision of the canonical Law, nor bring with it loosing from sins, if - by this act of Oikonomia - the basic principles stated by the penitential canonical Legislation of the Orthodox Church are affected.

\section{"Confession" and "Epitimia" in the See of the Confession}

During the age of the primary Church, "Loosing of the sins" and "Epitimias" were administrated both within the framework of the public Confession, and within that of the particular (individual) Confession, which supposed the keeping of the Secret of the Confession.

The statement according to which, "including in the primary period, the individual Confession preceded the public Confession," ${ }^{23}$ - to which some Orthodox theologians also adhered - has, however, no real justification, being infirmed both by Saint Basil the Great (cf. Canons 34 and 37), and by the Church Fathers of the Proconsular Africa of the second half of the $\mathrm{IV}^{\text {th }}$ century (cf. Canon 132 Synod of Carthage).

Since the practice of public Confession triggered unhappy consequences, both in the family life and in the life of the Christian Community, and, ipso facto, of the respective society, by the end of the $\mathrm{IV}^{\text {th }}$ century ${ }^{24}$ the Church

${ }^{21}$ Saint John Chrysostom says that this principle of leniency or condescension was expressed and used by Saint Paul the Apostle also in his relations with the Mosaic Cult, in order to win the adhesion of his fellows of the same Religion as he had been won once to the Christian Church. Cf. Joannes Chrysostomus, Homiliae 55 in Acta apostolorum. Homilia 46, in: Joannis Chrystostomi opera omnia quae exstant..., accurante J.-P. Migne, tomus nonus, Parisiis 1862, col. 323 (PG 60).

${ }_{22}^{2}$ Joannes Chrysostomus, Homiliae 55 in Acta apostolorum. Homilia 46, op. cit., col. 323 (PG 60); col. 636, 641 (PG 61).

${ }^{23}$ J. T. McNeill, A History of the Cure of Souls, New York 1951, p. 94, 98-99.

${ }^{24}$ Such a decision was made by the Archbishop Gennadios of Constantinopole (See I. N. Floca, Drept canonic ortodox. Legislaţie şi administraţie bisericească (Orthodox Canonical Law. Church 
forbid the practice of public Confession and gradually replaced it by that of individual (secret) Confession.

About this reality, clear testimonies come as well from the Fathers of the Church of the first millennium. For example, Saint Nicephorus the Confessor (IX ${ }^{\text {th }}$ century) forbid the Confessor to reveal the sins committed by the penitents, but he ought to advise them gently, so that they may remain repentant and to keep praying; and he ought to administrate the epitimias which befit each one of them according to their disposal of their souls.

According to the some Father of the Church, "as for adulterers, and those guilty of the crime of bestiality, and murderers, and other such persons, if of their own accord they confess the sin they committed, which was a secret to men at large, they are to be denied divine Communion and are to receive the canon of their sins... If, however, their sins are known to the others, then they are to be canonized in accordance with the laws of the Church" (Canon 28). ${ }^{25}$

Therefore, according to the advice of Saint Nicephorus, the Confessor has to take into account the spiritual disposal of every penitent and to administrate the Epitimias which befit to every person according to his best judgment, or - in terms of the text of the "Rudder" - "according to his best judgment" $(\text { Canon } 27)^{26}$

From the canon of Saint Nicephorus the Confessor, it has been also possible to note the fact that, beyond the Confessor's obligation to keep the Secret of the Confession, the Confessor needs to be "the image of gentleness" - as it was once the Holy Hierarch Nicholas - and to advise gently the penitent, who ought to persevere in "repentance" and "prayer."

In the See of the Confession, the penance - called "Epitimia" and, improperly, "Canon" - ought to have a corrective sense, which also gives its pedagogical, educative, character. By epitimia, the Confessor must not aim to punish the penitent, but to help him become aware of the gravity of his sins and give

Legislation and Administration), vol. 2, Bucharest 1990, p. 45). Here and there, and in isolated cases, the practice of public Confession shall continue, however, also in the $\mathrm{V}^{\text {th }}$ century.

${ }_{25}$ Apud N. Milaş, Canoanele Bisericii Ortodoxe însoţite de comentarii (The Orthodox Church Canons Accompanied by Comments), translation by U. Kovincici and N. Popovici, vol. 2, 2, Arad 1936, p. 238.

${ }_{26}$ Apud Neophitus, Patriarch of Constantinople, Pidalion. Cârma Bisericii Ortodoxe (The Rudder of the Orthodox Church), Iaşi 2004, p. 733. (As one can note, in The Rudder, Canon 28 of The Athenian Syntagma figures at no. 27). 
him the occasion of "new starts of virtuous life," uprooting "with all might the remains of the confessed sin, namely the reasons that give birth to $\sin .{ }^{27}$

In the Eastern Church, sin is perceived as " ... a disease causing the spiritual death of the person," and, for this reason, "the only healing from sin is the sincere repentance, which is realized by a penance process (epitimia)."28

This reality is also clearly certified by the orthodox canonical Doctrine, according to which "Epitimias" (Penances) "... have a therapeutical, not a legalistic character, and are given according to clear principles springing from the Holy Canons." ${ }^{29}$

The Epitimias having a therapeutical character, foreseen by the penitential Canons - starting with those of Saint Basil the Great and ending with those attributed to Saint John the Faster ( $\mathrm{X}^{\text {th }}$ and $\mathrm{xI}^{\text {th }}$ centuries $)$ - and the application of the Oikonomia in the See of the Confession have contributed both to the moderation of the rigorist spirit of the penitential Discipline, and also to an increased awareness regarding the notion of sin.

For these Epitimias to become, however, the necessary remedy for the healing from sins, the penitent ought to be totally sincere - this aspect being expressed by his confession of the truth regarding his sinful deeds - and his repentance ought to be sincere as well.

In Canon 3, Saint Basil the Great mentioned that "... a truer remedy is repu-

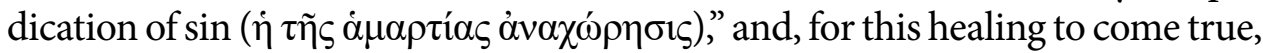
we need to follow both "what strictness ( strictly respect the letter of the law - and what has been settled by custom "( $\tau \tilde{\eta} \varsigma$

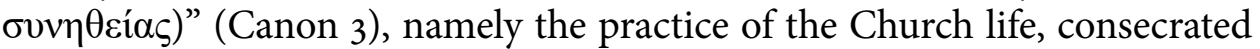
by the juridical custom of the Church.

The same Holy Father mentioned that not all the penitents can receive the Epitimias foreseen by the Acribia, namely the letter of the (canonical) Law, -

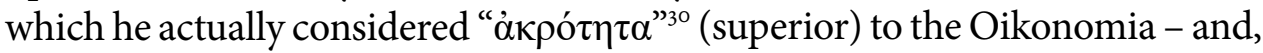

${ }^{27}$ C. Mavrula, Datoriile preoţilor (The Priests' Duties), București 1852, p. 134, apud E. Branişte, Din îțelepciunea şi experienţa duhovnicilor de odinioară (Out of the Wisdom and Experience of the Confessors of Yore), "Biserica Ortodoxă Română" (The Romanian Orthodox Church) 1960 no. 1-2, p. 151.

${ }^{28}$ L. J. Patsavos, Valenţele duhovniceşti ale sfintelor canoane (Spiritual Valences of the Holy Canons), translated by E. Tăvală, Sibiu 2012, p. 73.

29 L. J. Patsavos, Valenţele duhovniceşti, op. cit., p. 73.

${ }^{30}$ Canon 3 of Saint Basil the Great, apud I. Akantopoulos, The Collection of the Holy Canons and of the Church Laws, (in Greek), 2nd ed., Thessaloniki 1991, p. 514-516. 
for this reason, it is desirable to follow the customary practice imposed by the practical needs of the Church.

In his comment on this canon, the canonist Zonaras ( $\mathrm{XII}^{\text {th }}$ century) also mentioned that, in the Church, one ought to take into account both "the acribia of the law," and the power of the custom, namely of the customary (consuetudinal) law, but, when having in view the sinner's return to virtue, we need to prefer Oikonomia. ${ }^{31}$

The Orthodox canonists have also remarked the fact that, with Saint John Chrysostom, "the fundament of the oikonomia law" is the "principle of moderation," which needs to be applied especially "in the penitential domain."32

Regarding the Epitimias, Saint John Chrysostom ( $† 407)$ has indeed recommended the Confessors to avoid prescribing harsh Epitimias, and to prefer Oikonomia, taking into account first of all the sinner's intention to straighten up, and not the seriousness of the sin, because otherwise, “... trying to straight-

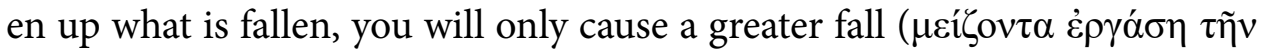
$\pi \tau \tilde{\omega} \sigma \mathrm{v}){ }^{,{ }^{33}}$

The same ecumenical Father says that the Confessor who thinks he could correct a sinner only by the severity of the epitimias, runs the risk of obtaining

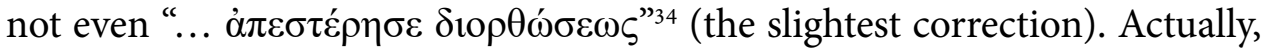
Saint John Chrysostom mentions that by the application of the Acribia, the

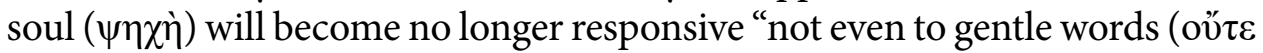

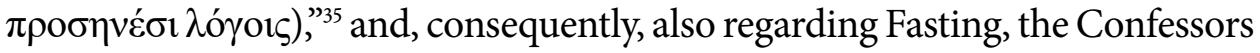

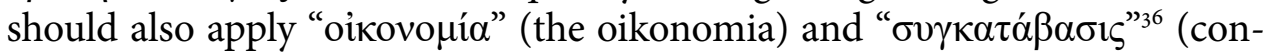
descension, namely "leniency").

The fact that, in the See of the Confession, the Confessor ought to apply the Oikonomia, and not the Acribia, is also confirmed by Canon 102 of the Trullan Synod (691/692), in whose text Saint Basil the Great is actually named and taken as a model also in point of the preference for Oikonomia.

${ }^{31}$ See J. Zonara, Comment on Canon 3 of St. Basil the Great, in: The Athenian Syntagma, op. cit., vol. 4, p. 100-101.

32 G. Cronţ, Dispensa şi Graţierea (Dispensation and Pardon), Bucharest 1937, p. 12.

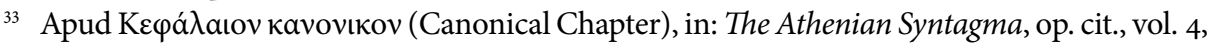
p. 387 .

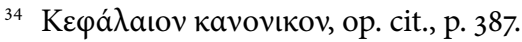

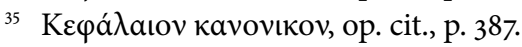

${ }^{36}$ Joannes Chrysostomus, Eclogae ex diversis homiliis. Homilia IV, in: Joannis Chrystostomi opera omnia quae exstant..., accurante J.-P. Migne, tomus duodecimus, Parisiis 1862, col. 597 (PG $63)$. 
From the text of the canonical Legislation of the Eastern Orthodox Church, one can notice as well that, in the spiritual therapy, has also functioned the principle "contraria contrariis curantur," because the penitent has always been advised to practice the virtue opposed to his sin in order to obtain the healing of his spiritual diseases (cf. Canon 102 Trullan Synod).

\section{The reduction of the Epitimias is conditioned by the "mode of repentance" and its "results"}

In a Guidance Discourse (П $\alpha \rho \alpha \gamma \gamma \varepsilon \lambda \mu \alpha$ ) addressed to his priests in the year 375, Saint Basil the Great asked them to be "worthy accomplishers of the Holy Canons," and not to administrate the Divine Eucharist "... to those to whom this is not allowed by the divine canons," ${ }^{37}$ therefore including to those who do not complete their Canon of repentance, namely the Epitimias received in the See of the Confession.

Regarding the duration of the "canon of the Confession," Saint Basil the Great leaves to "... good sense of judgment" of every Confessor "to increase the penalties or to relax them in accordance with the peculiarity of attending

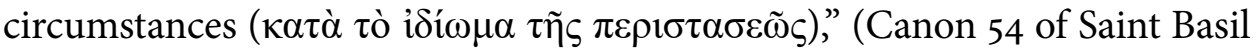
the Great). ${ }^{38}$

Regarding their diminution, the same Holy Ecumenical Father advises the Confessors to establish the duration of the Epitimias “... in every case with reference to time (period) [of the penance]," but taking into account “ $\tau \tilde{\varphi} \tau \tau \rho$ ó $\pi \omega$ $\tau \tilde{\eta} \varsigma \mu \varepsilon \tau \alpha v_{0} \alpha \varsigma^{\prime \prime 39}$ (the mode of repentance), and examining “... the fruits of re-

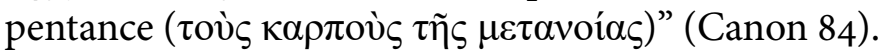

Based on Canon 12 of the I $^{\text {st }}$ Ecumenical Synod (Nicea, 325), any bishop has the canonical justification of applying - in the See of the Confession - the principle of the Oikonomia to those who demonstrate sincere repentance for their sins. But, "in addition to all these requirements it is requisite to examine into the will (or inclinations) and the kind of repentance. For as regards all those who with fear, and tears, and patience, and the doing of good to others have displayed proofs of their conversion by actual performance and not by mere

37 Apud N. Milaş, Canoanele Bisericii Ortodoxe, op. cit., vol. 2, p. 259. See also The Athenian Syntagma, op. cit., vol. 4, p. 391-392.

${ }^{38}$ Apud P. I. Akantopoulos, The Collection, op. cit., p. 551.

39 P. I. Akantopoulos, The Collection, op. cit., p. 564. 
pretense, ... the Bishop to devise some more philanthropic (or humane) treatment regarding them" (Canon $12 \mathrm{I}^{\mathrm{st}}$ Ecumenical Synod). ${ }^{40}$

It remains therefore up to the bishop to apply the principle of Oikonomia, which, for the Fathers of the It Ecumenical Synod, is actually expressed by a "gentler," more humane" decision, wherefrom the humane character that ought to be manifested by any act of Oikonomia in the See of the Confession.

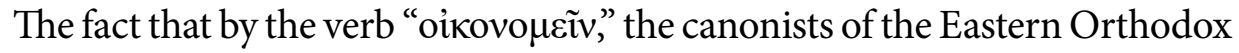
Church have also understood the "diminution" of the duration of the Epitimias, is also confirmed by Saint John the Faster in his "Kavovikòv," in which

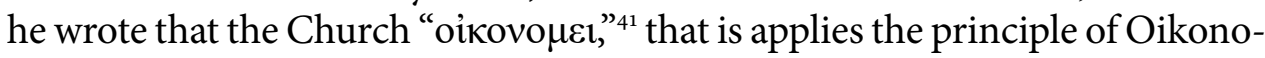
mia whenever the Epitimias are reduced in the See of Confession.

In his Comment on Canon 13 of Theophilus of Alexandria, Balsamon (XI$I^{\text {th }}$ century) uses also this verb only when he invokes the possibility of reducing the time (period) of the penance, through the application of the Oikonomia ${ }^{42}$ for two spouses (a man and a woman) who had been excommunicated, because they had concluded an "unlawful" Marriage, "being ignorant - according to their affirmation - of the laws of the Church" (Canon 13 Saint Theophilus of Alexandria).

In the Eastern Orthodox Church, the act of reducing the Epitimias has always been perceived as an act of Oikonomia, as it is attested not only by the canonical Legislation and its customary practice, but also by the Decisions of the Pre-Synodal Pan-Orthodox Conferences. For example, in the year 1986, the III ${ }^{\text {rd }}$ Pre-Synodal Pan-Orthodox Conference highlighted both "... the importance of Fasting in the Orthodox Tradition and in the present practice," and of "the principle of the Church Oikonomia, by which the local Churches have been given the possibility to adapt the institution (of Fasting) to the specific needs of their members." ${ }^{33}$

In the themes of the same Pre-Synodal Pan-Orthodox Conference, it has also been foreseen that ".. the Church ordained by Condescension the limits of the lenient Oikonomia regarding Fasting. Consequently, it foresaw the

${ }^{40}$ Apud Canoanele Bisericii Ortodoxe. Note şi Comentarii, op. cit., p. 59.

${ }^{41}$ Apud The Athenian Syntagma, op. cit., vol. 5, p. 433-435, 444.

${ }^{42}$ Balsamon, Comentariu la canonul 13 al Sf. Teofil al Alexandriei (Comment on Canon 13 of Saint Theophilus of Alexandria), in: The Athenian Syntagma, op. cit., vol. 4, p. 352.

${ }^{43}$ Comunicatul oficial al celei de-a III-a Conferinţe Panortodoxe Presinodale (Chambésy, 28 octombrie - 6 noiembrie 1986) (The Official Report of the IIIrd Pre-Synodal Pan-Orthodox Conference (Chambésy, 28 October - 6 November 1986)), "Episkepsis” 17 (1986) no. 366, p. 4-5. 
application of the ecclesial principle of the Oikonomia in the case of physical disease, of urgent need or because of the hardness of the times, according to the wit and pastoral care of the Bishops of the local Churches." 44

The same Pre-Synodal Pan-Orthodox Conference mentioned that "the Church set limitations to the Oikonomia regarding the permission of fasting ..., for those having problems due to ... personal reasons (disease, military service, work conditions, diaspora etc.), ..., to general reasons (special climate conditions in some countries, difficulties in finding food, social structures)," and let "to the wit of the local Orthodox Churches the setting ... of the level of Oikonomia allowed to alleviate the difficulty of the Holy Fasting Periods." 45

Consequently, the Confessor of our times is also obliged to take into account these Pan-Orthodox Decisions, and not just the provisions of some Canons, be they of Saint Basil the Great, of Saint John the Faster or of Saint Nicephorus the Confessor.

However, we ought to underline and retain the fact that, in the text of these Pan-Orthodox Decisions, explicit mention is made only about the obligation of applying the Oikonomia, and not the Acribia, because only the canonical topics have been considered, and not the dogmatic topics regarding the divine Oikonomia, which operate by the means of the Acribia.

In the case of "the Epitimias," or the so-called "penances," they need, however, to be "administrated" by the Confessor as he considers he ought to, but, according to the principle of the Oikonomia; they need to take into account both the spiritual state of every penitent, and the nature and the consequences of the sins confessed by the penitent (cf. Canon 1 Saint Gregory of Nyssa).

It is not by accident, therefore, that the Fathers of the Ecumenical Church have asked the Confessor to pay more attention to the manner of repentance ( $\dot{\lambda} \lambda \lambda \alpha \tau \tilde{\omega} \tau \rho o ́ \pi \omega \tau \tilde{\eta} \varsigma \mu \varepsilon \tau \alpha v o i ́ \alpha \varsigma)$ " and "not judge" the repentance "with the reference to time" (Canon 84 Saint Basil the Great).

The same Holy Ecumenical Father, Saint Basil the Great, affirms that "Repentance without Fasting is valueless," because "... it is not enough to refrain from certain foods for a praise-worthy Fasting: let us fast a Fasting well-pleasing and received by God. True Fasting is: become foreign to (become free from) evil; hold your tongue; abstain from anger; move away from lusts, from gossip, from lie, from perjury. Refraining from all these is - as the Holy Father

${ }^{44}$ Importanţa Postului şi respectarea lui astăzi (The Importance of Fasting and Its Observance Today), "Episkepsis" 17 (1986) no. 369, p. 6-8.

45 Apud the text published in "Episkepsis" no. 351 (1986), p. 7-9. 
concludes - the true Fasting, and, due to it (due to the refraining, our note), Fasting is a good thing." 46

It is not by accident that, in the See of the Confession, the Christians cannot receive "loosing" [the permission] for the Holy Communion if they have not respected the Fasting of the Church. Yet, also regarding Fasting, the Church has permitted that, by Oikonomia, "the sick" be absolved even of the obligation of observing the duration "of Holy Lent" (Apostolical Canon 69).

In this regard, the canonical Legislation of the Eastern Church foresees the empowerment of the Bishop - in his quality of Confessor - to absolve the penitent from accomplishing the Epitimias if he is in a state of dying. In the absence of the bishop - or with his permission - any Confessor Priest can grant this pardon and give the penitent the Holy Communion (cf. Canons 12 $\mathrm{I}^{\text {st }}$ Ecumenical Synod; $16 \mathrm{IV}^{\text {th }}$ Ecumenical Synod; $102 \mathrm{VI}^{\text {th }}$ Ecumenical Synod; 2, 5, 7 Ancyra; 6, 43 Carthage; 2, 54, 74, 84, 85 Saint Basil the Great; 4, 5, 7 Saint Gregory of Nyssa; 3 Saint Athanasius the Great; 3 Saint John the Faster).

If "the sick" require to be exempted from fasting on Wednesday and Friday, The Rudder asks them to get the opinion of a "skilled and God-fearing Doctor," who ought to also prescribe them an adequate diet, to help each of them "alleviate his weakness." Actually, in case of disease, "the bishop or the Confessor Priest" can "free" or "unbind" the sick from "Fasting," yet "he ought not to trust" only his words, namely he ought not to trust only the reasons invoked by the "sick," especially if they are of those "who call themselves of good lineage," ${ }^{47}$ namely if they are of the rich.

According to Saint Basil the Great, the reduction of Epitimias is also conditioned by two facts, that is by the "ignorance" of our deeds and by "willingness" to confess the sins," which really make us "worthy of forgiveness," and, consequently, it is useless to lengthen the penance (Canon 7). ${ }^{8}$

${ }^{46}$ St. Basil the Great, On Fasting, 1, 3; 2, 7, apud † Damaskinos Papandreou, Sfântul şi Marele Sinod al Ortodoxiei: Tematică şi lucrări pregătitoare (The Holy and Great Synod of the Orthodoxy. Topics and Preparatory Works), Iaşi 1998, p. 95-96.

47 Comment on the Apostolical Canon 69, in: Neophitus, Patriarch of Constantinople, Pidalion, op. cit., p. 120.

${ }^{48}$ Apud Canoanele Bisericii Ortodoxe. Note şi Comentarii, op. cit., p. 347. 


\section{The Confession of sins and the accomplishment of "the Canon of repentance," basic conditions for receiving the Holy Eucharist}

According to the orthodox canonical Legislation and Doctrine, the Confession of sins and the accomplishment of "the Canon of repentance," namely of the "Epitimias," are basic conditions for the receiving of the Holy Sacrament of the Eucharist $^{49}$ (cf. Canons 52 Apostolical; 6, 7, 43 Carthage), which can only be administrated to the Orthodox Christians who have confessed their sins in the See of the Confession and have received loosing (forgiveness) of their sins from their "Spiritual Father" (ó $\pi \varepsilon v \mu \alpha \tau \iota \kappa o ́ \varsigma \pi \alpha \tau \eta ́ \rho)$.

The Confession needs to be administrated, however, according to the provisions of the canonical Legislation (cf. Canons $12 \mathrm{I}^{\text {st }}$ Ecumenical Synod; 102 Trullan Synod; 3, 74, 84, 85 Saint Basil the Great), and not according to the routine, knowledge or pastoral measure of every confessor, and certainly, even less, according to some improvisations imposed by a routine of a Church practice, be it even in the See of the Confession.

Regarding the interdiction to partake of the Holy Eucharist, for a certain period of time, the Fathers of the ${ }^{\text {st }}$ Ecumenical Synod (Nicea, 325) decreed that "the old and canonical Law shall be kept even now, so that, if anyone is exciting, let him not be deprived of the final and most necessary viaticum" (Canon 13). Consequently, if the one who "is dying" (namely, the dying man, our note) were to ask to be "a partaker of the Holy Eucharist" (to receive the Holy Eucharist, our note), the Bishop or the priest "ought to give him the Holy Communion" (Canon 13 I $^{\text {st }}$ Ecumenical Synod)..$^{50}$

Therefore, the confessor cannot afford to refuse the administration of the Holy Eucharist to the Christian who - being on his death bed - asks for it with determination and repentance, "even if he had been banned from

49 Concerning this condition, see for more details C. Mititelu, Rânduieli şi norme canonice privind Sfânta Euharistie. Consideraţii de doctrină canonică (Canon Orders and Norms regarding the Holy Eucharist), in: Dimensiunea penitenţială şi euharistică a vieţii creştine (The penitential and Eucharistic dimension of the Christian life), coord. G. Petraru and L. Petcu, Iaşi 2014, p. 276; N. V. Dură, "Povăţuiri” şi "Învăţături”, cu conţinut liturgico-canonic, privind Sfânta Euharistie. Consideraţii eclesiologico-canonice ("Advices" and "Teachings" with a Liturgical-Canonical content, regarding the Holy Eucharist. EcclesiasticalCanonical Considerations), in: Dimensiunea penitențială şi euharistică a vieţii creştine, op. cit, p. 73-76; 78 and 100.

${ }^{50}$ I. N. Floca, Canoanele Bisericii Ortodoxe, op. cit, p. 59-6o. 
the Communion for his entire life,"51 because no Christian can be deprived of this "food of the eternal life." Certainly, by the administration of the Holy Eucharist in such a situation, the Confessor applies - based on the Rules of the Holy Fathers of the $\mathrm{I}^{\text {st }}$ Ecumenical Synod - also an obvious act of Oikonomia.

According to the norms foreseen by the same canonical Legislation of the Eastern Church, the Confession must be individual, namely private, and not collective. ${ }^{52}$ And, certainly, the Epitimias must also be given individually, and for a limited period of time, namely until the Confessor observes that the respective penitent has straightened up (cf. Canon 28 Saint Nicephorus the Confessor).

The orthodox canonical Legislation stipulates that a Confessor Priest cannot annul or to change "the Canon of repentance," alias "the Epitimia," prescribed by another Confessor (cf. Canons 32 Apostolical; 29 Carthage; 4 Antioch; 14 Sardica etc.). Epitimias can, however, be abrogated, changed or alleviated by the local Bishop (cf. Canons 11 and $12 \mathrm{I}^{\text {st }}$ Ecumenical Synod; $102 \mathrm{VI}^{\text {th }} \mathrm{Ecu}-$

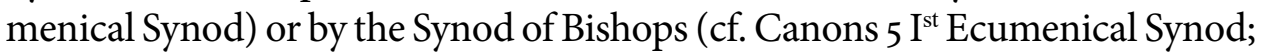
6 Synod of Antioch).

The same canonical Legislation forbids the Confessor Priest to administrate to anyone the Holy Eucharist before "the time has elapsed," namely before the duration of time prescribed as interdiction, as epitimia, for the receiving of the Holy Communion. An exception from this Order can be made - by the accomplishment of an act of Oikonomia - only when "the Confessor who gave this canon died;" when the penitent "is near death;" and when the confessor who gave the Epitimia cannot come, out of serious reasons. In these situations, ".. any priest can give this loosing (forgiveness), even when the bishop himself ordained - as the canonist Nikodim Milas, Bishop of Zara (Serbia), mentions the exclusion from the Eucharist," ${ }^{\prime 3}$ and, therefore, the excommunication of the respective penitent.

According to the Teaching of faith of the Orthodox Church, the place "most adequate where the Confession ought to be made, ... is the Church, namely

${ }^{11}$ N. V. Dură, “Povăţuiri” şi "Învăţături”, op. cit, p. 72.

${ }^{22}$ For this subject, see for more details K. Rhalli, On the Sacrament of the Confession according to the Law of the Eastern Orthodox Church (in Greek), Athens 1905.

${ }^{53}$ N. Milaş, Dreptul bisericesc oriental (Eastern Church Law), translated by D. I. Cornilescu and V. S. Radu, reviewed by I. Mihălcescu, Bucharest 1915, p. 462. 
in front of the Icon of our Savior Christ. Only the sick, or those who cannot come to Church can confess their sins at home." ${ }^{4}$

The same "Teaching of faith" mentions that a layman - except the children - cannot receive the Holy Eucharist "without the Confession (of sins)," 55 which acts end with "the reading of the loosing Prayers" and with the "Canon" ("Epitimias") prescribed by the Confessor "according to the kind of sins."

Regarding the "Canon," the Confessor has the canonical obligation of seeing if "the epitimias" or "the canon of the confession" prescribed have really awakened the penitent's conscience regarding the gravity and the consequences of the sins committed, and, certainly, if the penitent has used all the means provided in the See of the Confession to show "the fruit of repentance."

Out of the text of the Book of Teaching of the Eastern Orthodox Church (“Carte de Învăţătură a Bisericii Ortodoxe a Răsăritului”), drafted by the Romanian Metropolitan Peter Movila of Kiev (1596-1646), - which was first approved by the Pan-Orthodox Synod reunited in Iaşi in the year 1642, and then translated in Greek and approved by the Constantinopolitan Synod of the year 1643, - it is mentioned that "Epitimias do not aim to punish the sinner, but atonement of the sins and to help the sinner straighten up; they are - as the respective Pan-Orthodox Confession of Faith mentions - helpers, exercises reinforcing [the penitent] in virtue and driving [him] away from sin." 57

According to the testimony of the same Orthodox Teaching of Faith, "epitimias" are "means of repentance ordained by the confessor for the sinner who confesses his sins, such as, for instance: prayers, prostrations, Church going, acts of charity, fasting, refraining from certain foods or deeds and others. The hardest epitimia is not to be allowed to partake of the Holy Communion for a certain period of time." ${ }^{8}$

Therefore, according to the Teaching of faith of the Orthodox Church, Epitimias are nothing else except "means of repentance" which the Confessor prescribes to the penitent, starting with the Prayers and ending with the interdiction of the partaking of the Holy Communion.

However, the Confessor also has the pastoral-canonical obligation to check the manner in which these means are adequate for the respective penitents,

54 Invăţătura de credinţă ortodoxă (The Orthodox Teaching of Faith), Craiova 1952, p. 294.

55 Invăţătura de credinţă ortodoxă, op. cit., p. 295.

${ }_{56}$ Învăţătura de credinţă ortodoxă, op. cit., p. 294.

57 Îvvăţătura de credinţă ortodoxă, op. cit., p. 295.

58 Învăţătura de credinţă ortodoxă, op. cit., p. 295. 
and the way in which they help him or not in his educative-spiritual-religious process to their straightening up.

\section{"The Prayer of forgiveness" and "The Prayer of loosing," clear expressions of the application of the Oikonomia in the See of the Confession}

Saint John the Apostle says that, on the day of the Resurrection, “... breathing on them," Jesus said: "Receive the Holy Spirit” „if you forgive anyone's sins, their sins are forgiven; if you do not forgive them, they are not forgiven" (Jn 20:22-23)..$^{59}$

The orthodox biblical theologians say that "the Holy Spirit being breathed on them," the Apostles received the "grace of apostleship and priesthood," and, along with it, "also the power to forgive sins, operating in the Sacrament of the Confession or of the Confession of sins."

It is also the Lord Jesus Christ that told His "Disciples" (Mt 18:1): "whatever you bind on earth will be bound in heaven, and whatever you loose on earth will be loosed in heaven" (Mt 18:18). Consequently, the text of Matthew 18:18 clearly shows that this extraordinary power "to bind" and "to loose" men's sins on earth has been given to all the Apostles, and, by them, to their followers in the faith and in the grace of Christ.

In the text from Matthew 16:19, we find out, however, that the Lord has said the same thing to His "Disciples" through Peter, their spokesman. The Lord spoke "only to him because He wanted to use his name (Peter = rock) to define the solidity of the apostolical basis," ${ }^{31}$ and, at the same time, to highlight "the authority" that God has given "to the Church." ${ }^{2}$

Referring to the sense of the words "binding" and "loosing," from the texts of Matthew 16:19 and 18:18, the biblical theologians tells us that they refer to "... the spiritual power that our Savior Christ has given to the Apostles" and to the Church - by its hierarchic servants - to "bind and loose," which

59 Apud Holy Bible. The New Testament, King James Version. Red Letter Edition, 2009.

${ }^{60}$ I. Mircea, Dicţionar al Noului Testament (Dictionary of the New Testament), Bucharest 1995, p. 219.

${ }^{61}$ Biblia sau Sfânta Scriptură. Ediţia Jubiliară a Sfântului Sinod (The Bible or the Holy Scripture. Jubilee Edition of the Holy Synod), Bucharest 2001, p. 1480, n.a.

${ }_{62}$ Biblia de studiu pentru o viaţă deplină (Study Bible for an Abundant Life), Edited by Life Publishers International (Missouri/UsA), Bucharest 2000, p. 1325. 
mean "to organize, to legislate, to discipline, to excommunicate and to forgive or not the sins etc." ${ }^{3}$

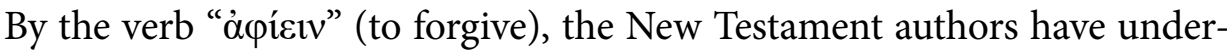
stood both "the forgiveness of a mistake or an offense" against God, made "by disobedience and sin," and "the forgiveness of our mistakes and sins," ${ }^{64}$ namely ours' and our fellows'. In some translations, from different Editions and Versions of the Book of John, the verb "to forgive" has been, however, replaced by the verb " $\lambda v \varepsilon^{\prime} v$ " to lose (Rom: a dezlega), wherefrom also the confusion produced among the authors of the different editions of the Old Slav Eucholo-

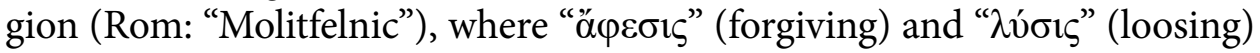
have the same meaning.

The same Holy Scripture tells us that, in His immeasurable love for mankind, God "... decided from beforehand to forgive and reconcile (men, our note) with Him. In this sense, He sent His Son in the world (John 3:16-17) to become man and to save it taking upon Himself the sins of mankind and atoning for them on the cross by His blood (Matthew 20:28; 26:26-28; Mark 15:22-23; Luke 22:19-20; Heb. 2:17; Ephesians 2:16; 1 Peter 1:17-18; 2: 24; 3: 18; 1 John 1:7; 4:10)." ${ }^{65}$

The fact that only Jesus Christ, the Son of God, has the power to forgive men's sins (cf. Mt 9:2, 5, 6; Mk 2:5, 7, 10; Lk 5:22-24; 7:47-48; In 5:8; 8:11), has been proven and stated explicitly by the Lord Himself during His activity on this Earth. Among other things, our Savior Jesus Christ asked His Apostles to "proclaim in His name repentance unto forgiveness of sins to all nations" (Lk 24:47; Acts 5:31; 10:43), because, “... these have been forgiven, sacrifice for sin is no longer necessary" (Heb 10:18).

The forgiveness of sins supposes, however, "the knowledge of salvation by the forgiveness of their sins" (Lk 1:77) and "repentance for the forgiveness of sins" (Mk 1:4; Lk 3:3). In other words, without "knowledge" and without "repentance"

${ }^{63}$ I. Mircea, Dicţionar, op. cit., p. 282.

${ }^{64}$ I. Mircea, Dicţionar, op. cit., p. 218-219.

${ }^{65}$ I. Mircea, Dicţionar, op. cit., p. 219.

${ }^{66}$ See N. V. Dură, Instruction and Education within the Themes of some International Conferences. An Evaluation of the Subjects Approached by these from the Angle of some Reports, Recommendations and Decisions, in: International Conference "Exploration, Education and Progress in the Third Millennium”. Proceedings, vol. 2, Galaţi 2009, p. 203-217; N. V. Dură, Man in the View of some Christian Theologians with Philosophical Background, "Annals of the Academy of Romanian Scientists, Series on Philosophy, Psychology, Theology and Journalism" 5 (2013) no. 1-2, p. 75-97; N. V. Dură, Statele Uniunii Europene şi cultele religioase (The States of European Union and the Religious Cults), "Ortodoxia" (The Orthodoxy) 1 (2009) no. 2, p. 49-72. 
there is no "forgiveness of sins" (Mt 26:28), which has been given to the whole human nation through Christ's sacrifice on the Cross of Golgotha.

The orthodox biblical Theology confirms that "those who after their Baptism fall into error and in heavy sins, if they confess their sins to the Confessor receive forgiveness in Christ's name (Jn 20:23) to be able to partake of the Holy Communion." "The forgiveness of sins" is therefore conditioned not just "by the faith in God and in the Sacrifice of our Savior Christ, a unique and universal Sacrifice," but also by the receiving of "the Holy Mysteries of the Church." ${ }^{68}$

For our daily sins, our Savior Jesus Christ has left us "The Lord's Prayer," by which we ask our Heavenly Father - among others - to "forgive our sins," assuring Him, however, that "we also forgive those who sin against us" (Mt 6:12), because - according to the Lord's word - if we do not forgive others their offenses, neither will our Father forgive our offenses (Mt 6:2, 14-15; 12:31; 18:21, 27, 32-35; Mk 3:28; Lk 12:10).

But, also from the text of some Canons one can actually notice that the application of the Oikonomia - in the See of the Confession - is ontologically

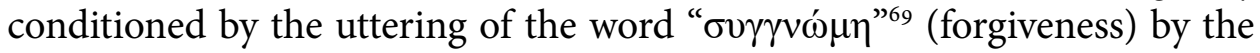
Confessor of the occasion of the "Prayer of forgiveness" and of the "Prayer of loosing," which he addresses to Jesus Christ, the only One Who actually forgives our sins.

Concerning the diminution of the Fasting period, the Confessor can only make use of the Oikonomia, as it has been foreseen actually both in the text of the Ecumenical Canonical Legislation (cf. Canons $8 \mathrm{I}^{\text {st }}$ Ecumenical Synod; $1 \mathrm{II}^{\text {nd }}$ Ecumenical Synod; $5 \mathrm{IV}^{\text {th }}$ Ecumenical Synod etc.), and in the text of some Decisions of the Pre-Synodal Pan-Orthodox Conferences, ${ }^{70}$ where it is mentioned that - regarding the duration of Fasting - it is left to the latitude of the local Church, that is of the local bishop and of its representative, the Confessor Priest. ${ }^{71}$

${ }^{67}$ I. Mircea, Dicţionar, op. cit., p. 219.

${ }^{68}$ I. Mircea, Dicţionar, op. cit., p. 219.

${ }^{69}$ Cf. Canon 8 Ist Ecumenical Synod; 2 and 12 Antioch; 7 Saint Basil the Great etc.

70 See N. V. Dură, Hotărârile celei de-a III-a Conferinţe Panortodoxe Presinodale (Cambésy Geneva, 28 octombrie 1986). O evaluare ecleziologico-canonică (The Decisions of the Third Pre-Synodal Pan-Orthodox Conference (Cambésy - Geneva, 28 October 1986). An Ecclesiological-Canonical Evaluation), “Ortodoxia" (The Orthodoxy) 40 (1988) no. 3, p. 75-102.

${ }^{71}$ See the text and the documents presented in "Episkepsis" no. 336 (1986), p. 3-4; no. 352 (1986), p. 2-21; no. 354 (1986), p. 2-22. 


\section{Only the Bishop has the canonical empowerment to diminish the Epitimias}

In Canon 74, Saint Basil the Great foresees that the bishop, who has been entrusted the power to "loose and to bind," and "if he see fit to exercise greater kindness, mitigate any excessive penalty imposed upon the one confessing his sin if he sees it to be excessive, by shortening the sentences, and in doing so he does not become worthy of condemnation, seeing that the history contained in the Holy Scriptures acquaints us with the fact that those who confess their sins with the greater painfulness soon have God's kindness bestowed upon them" (Canon 74 Saint Basil the Great).

Certainly, this diminution of the repentance time is nevertheless conditioned by the perseverance and sincerity of the penitent in the confession of sins in the See of the Confession.

In his comment on Canon 102 of the Trullan Synod, the Byzantine canonist

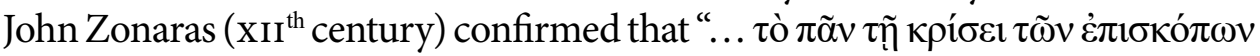

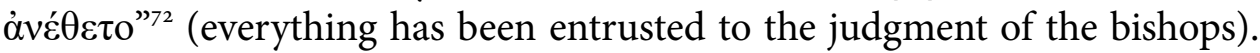

But, even "the bishops' right of Oikonomia" "... is submitted to some limitations."73 For example, "The Dispensations and the Pardons," which are "acts of extraordinary jurisdiction," cannot be approved by the bishops without "asking for the consent of the Synod of the respective Church or obtaining later on its approval." ${ }^{4}$ Therefore, this leads to the conclusion that "the exercise of the right of Oikonomia needs to remain under the guidance and the supervision of the synods." 75

According to the orthodox canonical Doctrine, "the priests can (they, too) exert the right of Oikonomia, either in their quality of confessors, or in their quality of holders of a part of ecclesial jurisdiction in the parishes they minister"76. Yet, the same doctrine mentions that, being "empowered of the bishops in the parishes, the priests cannot exert, however, the Church power, except under the supervision of the bishops." ${ }^{\prime 7}$

72 I. Zonara, Comment on Canon 102 of the Trullan Synod, in: The Athenian Syntagma, op. cit., vol. 2 , p. 550 .

73 G. Cronţ, Iconomia în Dreptul bisericesc ortodox, vol. 1, op. cit., p. 32.

74 G. Cronţ, Iconomia în Dreptul bisericesc ortodox, vol. 1, op. cit., p. 32.

75 G. Cronţ, Iconomia în Dreptul bisericesc ortodox, vol. 1, op. cit., p. 33.

${ }^{76}$ G. Cronţ, Iconomia în Dreptul bisericesc ortodox, vol. 1, op. cit., p. 33.

77 G. Cronţ, Iconomia în Dreptul bisericesc ortodox, vol. 1, op. cit., p. 33. 
The fact that this has been the teaching and the practice of the primary Church, is also confirmed by the text of the apostolical Canon 39, according to which "the priests and the deacons shall not accomplish anything without the approval of the bishop, because he is the one to whom the people of God has been entrusted and the one from whom an account for their souls shall be asked." ${ }^{8}$

In his comment on the $39^{\text {th }}$ apostolical Canon, the Byzantine canonist Aristen ( $\mathrm{XII}^{\text {th }}$ century) mentioned as well that a presbyter is not allowed "to increase of to diminish the penances" without the approval of the bishop. ${ }^{79}$ But, if we were to take into account this thing, a priest would not have this possibility not even in his quality of Confessor. This is, therefore, also the reason why some canonists insisted on the fact that the text of this canon should not be understood "... unilaterally, namely in the sense that indeed the priests and the deacons would not be able to accomplish anything without the approval of the bishop, but in the broader sense that also applies to the bishops via the $34^{\text {th }}$ apostolical Canon, namely not to accomplish anything of great importance without the approval of their superiors, namely metropolitan bishop, archbishop etc." ${ }^{80}$

The same canonists add the mention that the priest also holds the "grace-given power and the mission of sanctifying the believers' life and of leading them to salvation, and he undertakes this work of his based on his own right and not as a simple delegate of the bishop." ${ }^{\text {81 }}$ But, in some Statutes of organization and functioning of some Orthodox Churches, "the parish priest" is still mentioned as a "delegate of the bishop," ${ }^{82}$ and not an "empowered of the Bishop," ${ }^{83}$ as his true canonical status really is.

In order, to better clarify the true sense of the words in the text of the apostolical Canon 39, the same orthodox canonists mentioned - in their

78 Apud Canoanele Bisericii Ortodoxe. Note şi Comentarii, op. cit., p. 30.

79 Aristen, Comment on the 39th Apostolical Canon, in: The Athenian Syntagma, op. cit., vol. 2, p. 54 .

so Comment on the 39th Apostolical Canon, in: Canoanele Bisericii Ortodoxe. Note şi Comentarii, op. cit., p. 30.

${ }^{81}$ Comment on the 39th Apostolical Canon.

${ }^{82}$ Statutul pentru organizarea şi funcţionarea Bisericii Ortodoxe Române (The Statute of Organization and Functioning of the Romanian Orthodox Church), Bucharest 2008, Art. 49, p. 38 .

${ }_{33}$ Statutul pentru organizarea şi funcţionarea Bisericii Ortodoxe Române (The Statute of Organization and Functioning of the Romanian Orthodox Church), Bucharest 2003, Art. 47, p. 20. 
comment - that, doubtlessly "the priests and the deacons owe submission to the bishop," but that this canon reflects "the primary organizational state of the parishes, namely of the units led in the beginning by the bishops, units in which the priests and the deacons accomplished functions in a strict dependence of the bishop. When, later on, the priests acquired pastoral units, which they were guiding on their own responsibility, as the situation continues to be to this day, this strict dependence on the bishop, concerning any work of the priests, ceased, though they remain however submitted to the supervision and the control of the bishop, to whom they owe - as the respective canonists correctly conclude - canonical submission." ${ }^{44}$

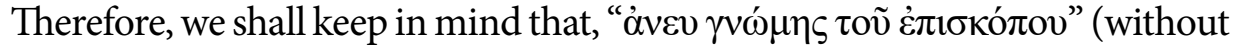
the bishop's permission), the priest - be he even a Confessor - cannot increase or diminish the Epitimias in the See of the Confession. Yet, we should not ignore or eclipse the fact that, by being ordained as a Confessor, the priest has acquired this permission from his local Bishop himself, and for this very reason he is allowed to also exert the right of Economy, namely to apply Oikonomia from case to case.

The fact that this was the reality in the primary Church is actually attested even by an apostolical Canon, based on which the Confessor Priest is empowered to grant a sick Christian an loosing from the fasting, if he were to be prevented from fasting by "bodily illness" (Canon 69 Apostolical).

As it had been mentioned also in the Comment in The Rudder, on this apostolical Canon, this thing is even clearer if, because of his illness, the doctor prescribed the respective Christian a certain diet, of which the confessor priest should also take heed as well in the See of the Confession, where he is empowered "to lose the Fasting" of "the sick." 85

Therefore, in exceptional cases, the Confessor Priest is also empowered to "loose" the penitent of certain interdictions foreseen by the Rules and Canons.

Instead of Conclusions, we can conclude that, from the analysis of the text of the canonical Legislation of the Eastern Church, corroborated with its canonical Doctrine, it has been possible to notice that "Acribia" and "Oikonomia" have been used in the Church even since the beginnings of its existence, but,

${ }^{84}$ Comment on the 39th Apostolical Canon, in: Canoanele Bisericii Ortodoxe. Note şi Comentarii, op. cit., p. 30.

${ }^{85}$ Apud Neophitus, Patriarch of Constantinople, Pidalion, op. cit., p. 120. 
in the See of the Confession, the application of the Oikonomia Principle has always prevailed.

The theological and canonical testimonies of the first millennium have also confirmed the fact that "Forgiveness" and "Loosing" are two obvious acts of Oikonomia, which the Confessor Priest use them in the See of the Confession in the name of Jesus Christ by the empowerment received from his canonical Bishop.

It has also been possible to notice the fact that the "Epitimias," which the Confessor prescribes to the penitent in the See of the Confession, are nothing else but a "Canon of love for man and of compassion," as the penitential Canons actually reminds us as well.

\section{Abstract}

In the See of the Confession, Oikonomia is perceived both as a "Saving Condescension" and as a "Canon of love for man." Therefore, the confessor needs to have always the conscience that by Oikonomia - which is above all an act of "redeeming condescension" - he can effectively help the sinner, and that, by this act, he is following in the footsteps of Christ, Who, out of His divine love for mankind, made of Himself a redeeming offering for the sins of the whole mankind.

From the analysis of the text of the canonical Legislation of the Eastern Church, corroborated with its canonical Doctrine, it has been possible to notice that "Acribia" and "Oikonomia" have been used in the Church even since the beginnings of its existence, but, in the See of the Confession, the application of the Oikonomia Principle has always prevailed.

\section{KeYwORDS}

the Confessor, the "Penitential Canons," the canonical Legislation

\section{Abstrakt}

\section{„Oikonomia" $\mathrm{i}$ jej zastosowanie w posłudze spowiedzi}

W posłudze spowiedzi "oikonomia" jest postrzegana zarówno jako „zbawcza łaskawość" i jako „kanon miłości do człowieka”. Dlatego spowiednik musi zawsze być świadom tego, że przez "oikonomia" - która jest przede wszystkim aktem „odkupieńczej łaskawości" - może skutecznie pomóc grzesznikowi i że przez ten akt naśladuje Chrystusa, który z Boskiej miłości do ludzkości uczynił siebie odkupieńczą ofiarą za grzechy całej ludzkości. Na podstawie analizy tekstów kanonicznego prawodawstwa 
Kościoła wschodniego, potwierdzonego doktryną kanoniczną, można zauważyć, że "acribia” i „oikonomia” były stosowane w Kościele już od początku jego istnienia, ale w posłudze spowiedzi zastosowanie zasady "oikonomia" zawsze przeważało.

\section{SłOWA KLUCZOWE}

Spowiednik, „Kanony pokutne”, prawodawstwo kanoniczne

\section{BIBLIOGRAPHY}

Akantopoulos I., The Collection of the Holy Canons and of the Church Laws, (in Greek), $2^{\text {nd }}$ ed., Thessaloniki, 1991.

Biblia de studiu pentru o viaţă deplină (Study Bible for an Abundant Life), ed. by Life Publishers International (Missouri/UsA), Bucharest 2000.

Biblia sau Sfânta Scriptură. Ediţia Jubiliară a Sfântului Sinod (The Bible or the Holy Scripture. Jubilee Edition of the Holy Synod), Bucharest 2001.

Branişte E., Din înţelepciunea şi experienţa duhovnicilor de odinioară (Out of the Wisdom and Experience of the Confessors of Yore), "Biserica Ortodoxă Română" (The Romanian Orthodox Church) 1960, no. 1-2, p. 141-160.

Canoanele Bisericii Ortodoxe. Note şi Comentarii (The Canons of the Orthodox Church. Notes and Comments), ed. by I. N. Floca, Bucharest 1992.

Comunicatul oficial al celei de-a III-a Conferinţe Panortodoxe Presinodale (Chambésy, 28 octombrie -6 noiembrie 1986) (The Official Report of the III ${ }^{\text {rd }}$ Pre-Synodal Pan-Orthodox Conference (Chambésy, 28 October - 6 November 1986)), „Episkepsis” 17 (1986) no. 366, p. 4-5.

Cronţ G., Dispensa şi Graţierea (Dispensation and Pardon), Bucharest 1937.

Cronţ G., Iconomia in Dreptul bisericesc ortodox, vol. 1: Principii (Oikonomia in the Orthodox Church Law), Bucharest 1937.

Dură N. V., "Povăţuiri” şi "Învăţături", cu conţinut liturgico-canonic, privind Sfânta Euharistie. Considerații eclesiologico-canonice ("Advices" and "Teachings" with a Liturgical-Canonical content, regarding the Holy Eucharist. Ecclesiastical-Canonical Considerations), in: Dimensiunea penitenţială şi euharistică a vieţii creştine (The penitential and Eucharistic dimension of the Christian life), coord. G. Petraru and L. Petcu, Iaşi 2014, p. 73-100.

Dură N. V., Despre "Jus naturale". Contribuţii filosofico-juridice (About "Jus naturale". Philosophical-juridical contributions), "Revista de Teologie Sfântul Apostol Andrei" (Theological Journal Saint Andrew the Apostle) 18 (2014) no. 1, p. 39-52.

Dură N. V., Dreptul în percepţia Părinţilor Bisericii ecumenice din primul mileniu (Law in the Perception of the Fathers of the Ecumenical Church of the First Millennium), 
"Revista de Teologie Sfântul Apostol Andrei” (Theological Journal Saint Andrew the Apostle) 10 (2006) no. 1, p. 7-16.

Dură N. V., Dreptul la demnitate umană (Dignitas Humana) şi la libertate religioasă. De la "Jus naturale" la "Jus cogens" (The Right to Human Dignity (Dignitas Humana) and Religious Freedom. From "Jus naturale" to "Jus cogens"), "Ovidius University Annals. Series: Law and Administrative Sciences” 2006 no. 1, p. $86-128$.

Dură N. V., Hotărârile celei de-a III-a Conferinţe Panortodoxe Presinodale (Cambésy Geneva, 28 octombrie 1986). O evaluare ecleziologico-canonică (The Decisions of the Third Pre-Synodal Pan-Orthodox Conference (Cambésy - Geneva, 28 October 1986). An Ecclesiological-Canonical Evaluation), "Ortodoxia" (The Orthodoxy) 40 (1988) no. 3, p. 75-102.

Dură N. V., Ideea de Drept. "Dreptul”, "Dreptatea" şi "Morala” (The Idea of Law. The "Law", The "Justice" and The "Morals"), "Ovidius University Annals. Series: Law and Administrative Sciences" 2004 no. 1, p. 15-46.

Dură N. V., Instruction and Education within the Themes of some International Conferences. An Evaluation of the Subjects Approached by these from the Angle of some Reports, Recommendations and Decisions, in: International Conference "Exploration, Education and Progress in the Third Millennium". Proceedings, vol. 2, Galaţi 2009, p. 203-217.

Dură N. V., Le jugement et la déposition des Evêques selon la legislation canonique conciliaire, ocumenique, du Ier millenaire, in: In memoriam Akademiemitglied professor Protopresbyter Dr. Stefan Tsankov, Sofia 2014, p. 117-128.

Dură N. V., Loi morale, naturelle, source du Droit naturel et de la Morale chrétienne, in: La morale au crible des religions (Studia Arabica XxI), coord. M. Th. Urvoy, Paris 2013, p. 213-233.

Dură N. V., Man in the View of some Christian Theologians with Philosophical Background, "Annals of the Academy of Romanian Scientists, Series on Philosophy, Psychology, Theology and Journalism" 5 (2013) no. 1-2, p. 75-97.

Dură N. V., Rânduieli şi norme canonice privind administrarea Sfintei Euharistii (Rules and canonical Norms rearding the administration of the Holy Eucharisty), in: Spovedania şi Euharistia izvoare ale vieţii creştine (Confession and Eucharisty Sources of the Christian life), vol. 2, Bucureşti 2014, p. 465-484.

Dură N. V., Statele Uniunii Europene şi cultele religioase (The States of European Union and the Religious Cults), "Ortodoxia" (The Orthodoxy) 1 (2009) no. 2, p. 49-72.

Dură N. V., Mititelu C., Human rights and their universality. From the rights of the "individual" and of the "citizen" to "human" rights, in: International Conference "Exploration, Education and Progress in the Third Millennium". Proceedings, vol. 1, no. 4, Galaţi 2012, p. 103-127. 
Dură N. V., Mititelu C., L'École roumaine du Droit canonique et sa contribution au développent du Droit canonique de l'Église Orthodoxe Ecuménique, in: Tradiţie şi continuitate în teologia tomitană. Două decenii de învăţământ teologic universitar la Constanţa (1992-2012) (Tradition and Continuity in the Theology of Tomis. Two Decennia of Theological Higher Education in Constanta), Constanţa 2012, p. 37-6o.

Floca I. N., Drept canonic ortodox. Legislaţie şi administraţie bisericească (Orthodox Canonical Law. Church Legislation and Administration), vol. 2, Bucharest 1990. Holy Bible. The New Testament, King James Version. Red Letter Edition, 2009.

Iconomia în Biserica Ortodoxă (Referat al Comisiei Interortodoxe pregătitoare a Sfântului şi Marelui Sinod, Chambésy, 16-28 Iulie 1971) (Oikonomia in the Orthodox Church. Report of the Inter-Orthodox Commission preparatory for the Holy and Great Synod, Chambésy, July 16-28, 1971), “Ortodoxia” (The Orthodoxy) 24 (1972) no. 2, p. 286-290.

Importanţa Postului şi respectarea lui astăzi (The Importance of Fasting and Its Observance Today), "Episkepsis" 17 (1986) no. 369, p. 6-8.

Invăţătura de credinţă ortodoxă (The Orthodox Teaching of Faith), Craiova 1952.

Kotsonis I., Problèmes de l'Economie éclésiastique, éd. J. Duculot, Ganbloux 1971.

L'Hullier P., L'Esprit du droit canonique, in: Messager de l'Exarchat du Patriarcat Russe en Europe Occidentale, Paris 1964, p. 46-47.

McNeill J. T., A History of the Cure of Souls, New York 1951.

Milaş N. Dreptul bisericesc oriental (Eastern Church Law), translated by D. I. Cornilescu and V. S. Radu, reviewed by I. Mihălcescu, Bucharest 1915.

Milaş N., Canoanele Bisericii Ortodoxe însoţite de comentarii (The Orthodox Church Canons Accompanied by Comments), translation by U. Kovincici and N. Popovici, vol. 2, 2, Arad 1936.

Mircea I., Dicţionar al Noului Testament (Dictionary of the New Testament), Bucharest 1995.

Mititelu C., Rânduieli şi norme canonice privind Sfânta Euharistie. Consideraţii de doctrină canonică (Canon Orders and Norms regarding the Holy Eucharist), in: Dimensiunea penitenţială şi euharistică a vieţii creştine (The penitential and Eucharistic dimension of the Christian life), coord. G. Petraru and L. Petcu, Iaşi 2014, p. 276.

Mititelu C., The application of Epitimias in the See of Confession according to the "Canonical Custom" and the "Penitential Canons", "Teologia Młodych" 2015 no. 4, p. 10-18.

Mititelu C., The celebrant of the Holy Sacrament of the Eucharist. Rules and canonical norms of the Orthodox Church, "Annales Canonici" 2014 no. 10, p. 135-148.

Neophitus, Pidalion. Cârma Bisericii Ortodoxe (The Rudder of the Orthodox Church), Iaşi 2004. 
New Commentary on the Code of Canon Law, ed. by J. P. Beal et all., New York 2000. Papandreou D., Sfântul şi Marele Sinod al Ortodoxiei: Tematică şi lucrări pregătitoare (The Holy and Great Synod of the Orthodoxy. Topics and Preparatory Works), Iaşi 1998.

Patsavos L. J., Valenţele duhovniceşti ale sfintelor canoane (Spiritual Valences of the Holy Canons), translated by E. Tăvală, Sibiu 2012.

Photios, Preface to the Nomocanon in XIV Titles, in: The Athenian Syntagma, vol. 1, ed. by G. A. Rallis și M. Potlis, Athens 1852, p. 4-5.

Rhalli K., On the Sacrament of the Confession according to the Law of the Eastern Orthodox Church (in Greek), Athens, 1905.

Statutul pentru organizarea şi funcţionarea Bisericii Ortodoxe Române (The Statute of Organization and Functioning of the Romanian Orthodox Church), Bucharest 2008.

Statutul pentru organizarea şi funcţionarea Bisericii Ortodoxe Române (The Statute of Organization and Functioning of the Romanian Orthodox Church), Bucharest 2003.

Stăniloae D., Iconomia dumnezeiască, temei al iconomiei bisericeşti (The Divine Oikonomia, Basis of the Church Economy), "Ortodoxia” (The Orthodoxy) 21 (1969) no. 1, p. 3-24.

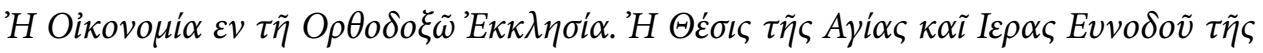

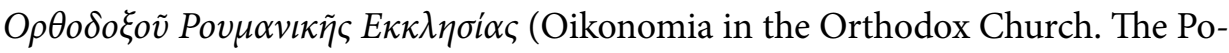
sition of the Romanian Orthodox Church Synod), translated in Greek by O. Căciulă, Bucharest 1969. 